\title{
JOHN AUTHER, PHILOMUSUS
}

\author{
By ROBERT A. AUBIN
}

Dr. Aubin, as most of our readers will know, is a member of the faculty of the New Jersey College for Women. A year or two ago he published, as Rutgers University Studies in English, Number Three, a collection of poems on the Great Fire of London, entitled LONDON IN FLAMES, LONDON IN GLORY. $H e$ is also the author of TOPOGRAPHICAL POETRY OF THE EIGHTEENTH CENTURY.

T F simple rarity as such is to be prized, the Rutgers Library may be congratulated on its possession of a London publication of 1 I 777, the work of one John Auther, "Philomusus." This volume, entitled Poems on Various Occasions, is listed in the Catalogue of the British Museum, but to the best of my knowledge ours is the only copy in America. It is a nicely printed book of some I 20 pages and was formerly sold by Lewis in Paternoster Row and the Dillys in the Poultry.

Another John Auther, labeled "the Elder" in the British Museum Catalogue, was almost certainly the father of our poet. This Auther was a divine (probably nonconformist) in the country town of Waltham Abbey, and two of his published sermons have been preserved. But more interesting for us is the fact that he was a poet: in 1753 The Monthly Review ${ }^{1}$ described a second edition of his Divine Poems on Various Subjects, to which an elegy in Latin and English to the memory of the Reverend Philip Doddridge had been prefixed. The funeral sermon of Auther père was preached by the Reverend Benjamin Wallin in $1761 .^{2}$

John Auther fils has left no trace of himself outside Poems on Various Occasions. He seems to have lived like his father in Waltham Abbey, for from that town he dated the dedication of his book to his "Worthy Subscribers," not fewer than fifty-one of whom were residents. We may assume, also, that his family was fairly large and devoted, for three male and three spinster Authers were among these subscribers. However, this family appears to have been neither an old established one nor notably prosperous: it is not mentioned in

${ }^{1} \mathrm{IX}, 236$.

${ }^{2}$ Monthly Review, XXVII (1762), 237. 
Essex County histories, the poet acknowledges light-heartedly his own limited means, and in February I 783 The Gentleman's Magazine ${ }^{3}$ included in a list of " $\mathrm{B}[\mathrm{A}] \mathrm{NK}[\mathrm{RUP}] \mathrm{TS}$ " the names of John and Thomas Auther of London, "insurance-brokers." "

The poet's environment was no more brilliant than his position in life seems to have been. Waltham Abbey was no large center of either trade or culture. In 1772 its quiet attracted young Richard Brinsley Sheridan to sojourn there until the stir occasioned by his recent duel near Bath had subsided and his wounds had healed. In I 8 I I it included only $4 \mathrm{I} 4$ houses and 2287 inhabitants. ${ }^{5}$ The one building of note was the once magnificent abbey, which may have housed the tomb of Harold Infelix and had had no less famous a chronicler than Thomas Fuller.

In keeping with all this lack of distinction, the poems of John Auther are by no means remarkable. Indeed, the reader is vaguely conscious of having read them before somewhere, for with one or two exceptions presently to be noticed, both ideas and forms are conventional. Still, to understand an age, one must read not its geniuses merely but its mediocrities as well; and Auther at least throws light on English provincial taste during the years of the War of American Independence.

His volume is as interesting for what it has not as for what it has. Here are no Pindaric odes, epigrams, parodies, marriage odes, sonnets, "arts" or "progresses" of this or that, Day of Judgment pieces, grotto poems; no Ossianic effusions, odes to evening, essays on ut pictura poesis, or verses on a sleeping infant; the poet bothers not with mystical lore or even with groans from the graveyard, and he completely ignores Nature whether rob'd or not by Elegancy's hand. In short, compared with perhaps the majority of poets of his day, he is a writer of exceedingly limited and conservative tastes. He admires Homer and other Greeks, Virgil, Horace, Cervantes, Milton to some extent, Butler, Pope, and Churchill; his favorite genres are formal satire, fable, and Horatian imitation; and his verse-forms are restricted to heroic and octosyllabic couplets. Only in his Whiggism does he incline toward more liberal views.

${ }^{3}$ LIII, I 83.

4 This John Auther was probably not the poet but he who had headed the list of subscribers to his kinsman's book.

${ }^{5}$ Anon., Excursions in the County of Essex (London, I8I9), II, 28. 
The opening and most pretentious poem of the collection, "The Vision," is a formal satire in heroic couplets wherein the maid Reason exposits the shortcomings of various social types. This is a belated example of the old-fashioned poem of sustained satire to which Charles Churchill had recently given a few years of borrowed time before it finally was retired in favor of the satirical ballad, ode, and pamphlet. ${ }^{6}$ Although the satire is to a degree impersonal, the poet reveals some individuality toward the end, when he turns from denunciation of "Luxury" and persecution to praise of the American colonists.

This and one or two other serious pieces are followed by a number of lighter and more intimate poems in octosyllabics: "The Power of Wine," "The Laughing Philosopher," "The Gout." In these the clergyman's son proclaims with dubious sincerity (one suspects a private joke) a Horatian and even Anacreontic philosophy of life. Badinage unquestionably pervades "The Antient Female Worthies," a demonstration through biblical and classical examples that "Dear, lovely woman rules the Roast." But in all this there is nothing to flutter the most susceptible, even in that age of âmes sensibles.

But only one of Auther's poems can be pronounced really philosophical, and that, characteristically, is derivative. "The Golden Chain" provides a fairly late example of the Chain of Being idea, which, with its corollary of "whatever is is right," served so many for so long in keeping so many others where they belonged. Yet Auther elsewhere expresses admiration not only of the American colonists, as we have seen, but even of Churchill and Wilkes; and in this poem he diverts the traditional weapon of Toryism from the heart of the democratic ideal by emphasizing that

every One in his Degree

Adds somewhat to Society,

that the achievements of the Caesars have been made possible only by the willing cooperation of the little people. Thus for Auther the doctrine of the Chain of Being had not quite the same social implications that it had for that Bishop of Llandaff whose remarks in a sermon published some years later infuriated a young Jacobin named William Wordsworth.

${ }^{6}$ Joseph M. Beatty, Jr., "Churchill's Influence on Minor Eighteenth Century Satirists," $P M L A$, XLII (March 1927), 162. 
Finally, in "Contentment" Auther expresses his conception of the abundant life. For him the summum bonum is mental peace:

Contentment! Soul-reviving Pow'r,

Oh! take me to thy peaceful Bowr;

For ever let me there remain,

One of thy happy rural Train.

False World, away! thy boasted Joys

Are, at the best, deceitful Toys;

Who trusts to thee shall never know

The Sweets that from Contentment flow.

These lines reveal the poet once more as completely of his age, which liked to dally with this negative response to life. The reader who loves to wander down forgotten byways of eighteenth-century poetry is continually discovering hymns to "mediocrity" or "indifference," the middle way between emotional extremes. Here, for example, is the Reverend John Free writing "On the Government of Our Passions": ${ }^{7}$

O! who shall teach me to sustain,

A more than manly Part?

To go thro' Life, nor suffer Pain

Nor Joy to touch my Heart.

Thou blest Indifference, be my Guide,

I court thy gentle Reign;

When Passion turns my steps aside,

Still call me back again.

This attitude, of complicated classical-puritanical provenience, quite suited Auther. In "Contentment" he exclaims:

Vain World, away! thy Smiles no more

Shall tempt me from this peaceful shore;

Here let me rest, whilst round my Head

The Goddess doth her Blessings shed.

May John Auther, to borrow the words of the materialistically religious, be resting in peace.

${ }^{7}$ Poems and Miscellaneous Pieces (London, $175 \mathrm{I}$ ), p. 98. 